\title{
The idea for... biobank - just a few words
}

Joanna Uchańska

DOI: $10.24131 / 3247.170104$

Summary:

The use, collection and modification of human biological material/the human body is a difficult, controversial and challenging subject demanding deep analyses of all the ethical, social and legal aspects. Use of the human body for experimental purposes for or without the reward is often criticized. It is clear, however, that not all researches on new medicinal products, medical devices or cosmetics can be carried out on animals only. Contribution of a human being in experiments and clinical trials (including organs, tissues or cells) is the only way to verify safety and efficacy of a tested method or substance. Storage of human biological material intended for tests demands meeting conditions provided by legal standards and showing respect for the human body and human dignity; that is why biological material must be, as a rule, stored in cell and tissue banks (biobank). Any entity that wants to operate a bio-

received: 19.09.2016; accepted: 23.01.2016; published: 18.04.2017

mgr Joanna Uchańska: PhD student

in the Chair of Intellectual Property Law

of the Faculty of Law and Administration

Jagiellonian University in Cracow

\section{Basic legal status}

EU regulations on transplantation can be found in respective directives. Standards on quality and safety for the donation, procurement, testing, processing, preservation, storage and distribution of human tissues and cells and products derived from them intended for human applications are covered by Directive 2004/23/EC bank must meet a number of complex requirements before entering this narrow, difficult and demanding market. This is the result of legislative chaos and fragmentation of laws at the national and EU level, but also social, ethical or religious prejudice. However, biobanks are an indispensable research tool for understanding genetic or environmental grounds of many diseases, e.g. hereditary ones. Biobanks can undoubtedly revolutionize the health market and contribute to the further development of personalized medicine. However, the entity willing to establish a cell and tissue bank must meet and take into account several criteria. Any entity considering the foundation of a biobank wonders whether this activity will be profitable and whether it can be included in the chain of clinical trials.

Key words: biobank, human biological material

(art. 2, item 1). In accordance with the Directive, a cel and tissue bank (biobanks) is a bank or a unit of a hospital or another body where activities of processing, preservation, storage or distribution of human tissues and cells are carried out. The facility of this type can be also responsible for collection or testing of tissues and cells (art. 3 point o) of the Directive). The Directive does not, however, define what the term of testing tissues and cells means. Detailed rules on this matter have been included in the provisions of the Polish Act of 1 July 2005 on the collection, storage and transplantation of cells tissues and organs (hereinafter: the Transplant Act; detailed information on the law, no, etc. is missing).

\section{Qualification of cell and tissue banks}

Art. 1 of the Transplant Act determines the rules for the collection, storage and transplantation of cells, including hematopoietic cells of bone marrow, peripheral blood and umbilical cord blood, tissues and organs derived from a living donor or a cadaver, as well as the principles of testing, processing, storage and distribution of human tissues and cells. Although the law defines a cell and tissue bank as an organizational unit operating in the collection, processing, sterilization, storage and distribution of tissues and cells, which can also collect or test tissues and cells (art. 2 item 1 point 1 ), art. 25 determines explicitly that cell and tissue banks are created for the collection, processing, sterilization, storage and distribution of tissues and cells for transplantation. In addition, art. 2 item 1 point 14 clarifies that testing within the meaning of the Act are any operations that involve tests determining the suitability of cells, tissues or organs for transplantation in humans. From the analysis of the provisions of the Directive and the Polish Act one can draw a conclusion that the wording of the Directive that regulates handling of human tissues and cells "intended for human use" has a broader meaning than the one introduced in Polish law using the term of "transplantation". Due to the wording of the regulations, cell and tissue banks in Poland performing operations not intended for transplantation cannot be recognized as cell and tissue banks. Therefore, for the qualification of the entity it is essential to define the use of cells and tissues. If the cells or tissues are processed, 
stored, etc. beyond this intention, we cannot talk about a biobank. This is the first criterion to be taken into account when creating a biobank.

In addition, it should be noted that the same Transplant Act also applies when cells, tissues or organs are obtained in connection with their removal during some other medical intervention carried out as a treatment not a transplantation procedure (art. 21 of the Transplant Act). The acquisition and the use of such acquired parts of the body, however, requires adequate notification of the donor and receipt of donor's conscious, informed and prior consent (art. 22 of the Bioethics Convention).

However, it appears that there are no cons to operate a biobank for the purposes of an experimental medical treatment (introducing new or partially proven diagnostic, therapeutic or prophylactic method by the physician to achieve direct health benefits by a person being treated or a particular patient) and an experimental medical research (intended for expanding medical knowledge and conducted on healthy and ill people; permissible if participation in it is not associated with the risk, or the risk is low and is not disproportionate to the potential positive results of such an experiment), in particular a clinical trial being a type of an experimental research (in accordance with art. 21 of the Act on practicing professions of a physician and dentist (OJ 2008, No. 136, item 857).

Some biobanks uniquely qualify their operations as focused on the collection, processing, storage and distribution of cells which are the subject of scientific research, which will be eventually used in humans (such as Biobank at the University of Warmia and Mazury in Olsztyn, Faculty of Medical Sciences; poltransplant.org. pl). The use of stem cells is of particular importance in researches on medicinal products. Thus stem cell banks constitute important support in conducting clinical tri- als. Among the certified stem cell banks one can find for instance: Public Stem Cell Bank in Chęciny at the Regional Centre for Science and Technology; Diagnostyka Stem Cell Bank Sp. o.o. in Cracow; Progenis - Stem Cell Bank in Krakow; Cell Bank of the Department of Cell Biology of the Faculty of Biochemistry, Biophysics and Biotechnology at the Jagiellonian University; Bank of the Laboratory of Cell and Tissue Engineering of the Malopolska Biotechnology Centre. Conducting clinical studies using stem cells contributes to the development of personalized medicine in a special way - allows for specific therapy tailored not only for a specific disease, but for specific groups of patients or selected patients, including searching for effective treatments (of cancers for instance).

For this reason, this sort of entity is established to acquire human tissues and their preparation for human use (processing, preparation, processing), storage and distribution in accordance with accepted legal principles and technical standards (Komender 2004, 13-17). But there is no requirement that each unit must perform all the activities referred to in art. 2 item 1 point 1 of the Transplant Act.

Therefore, an entity that aspires to be a biobank must meet a number of requirements, in particular to obtain a permit from the Minister responsible for health affairs to carry out the planned activities (art. 25 of the Transplant Act) and to follow the requirements of the Transplant Act in this regard.

\section{How to obtain a permit to conduct a biobank}

Any entity willing to operate a biobank must submit an application for an administrative decision allowing such activities (art. 27, item 5 of the Transplant Act). Therefore, in accordance with art. 26 item 2 of the Transplant Act, any entity applying for authorization submits an application to the National Center for Tissue and Cell Banking (hereinafter: the Center).

The application for the permit should reflect the type and the scope of planned activities and specify both types of tissues and cells, as well as all the operations that they will be subject to. For example, the application can include:

- "gathering, processing, storage and distribution of hematopoietic cells of bone marrow and peripheral blood for transplantation purposes";

- "collection, testing, processing, storage and distribution of hematopoietic cells of umbilical cord blood";

- "collection, processing, sterilization, storage, testing and distribution: allogeneic and autologous musculoskeletal grafts, allogeneic and autologous

Person responsible meets the requirements of art. 28 item 2 of the Transplant Act, so she/he has at least higher education in the field of medical or biological sciences and two years of professional experience gained in a biobank or entities operating in the field of processing, preservation, storage, distribution, collection and testing of human tissues and cells.

Elements of the applications (art. 26 item 6 of the Transplant Act)

- Document identifying a person authorized to represent the entity - Information on the number of employees and their qualifications (these persons should go through a special training)

- Opinion state sanitary inspector on meeting the requirements set out in the Regulation of the Minister of Health dated on 20 Novem ber 2006 on professional sanitary requirements for cell and tissue banks (Journal of Laws No 218, pos. 1598

- List of rooms and devices, organizational structure, responsibilities of employees, expected scope of activities

- List of cooperating entities having impact on the quality and safety of tissues, plus detailed specification of recommended activities along with carbon copies of agreements concluded with these entities

Name of the person responsible for following the Transplant Act in the entity 
mucosal and connective tissue grafts, allogeneic and autologous blood vessel grafts, allogeneic and autologous cell grafts" (examples from http:// www.poltransplant.org.pl/banki.html; access: 12.01.2017)

According to art. 26 item 5 of the Transplant Act, a biobank shall obtain a license to operate within the declared scope as far as it meets the following conditions:

- It employs qualified personnel, including a person responsible for ensuring that the biobank follows the provisions of the Transplant Act and the rules laid down in the quality assurance system;

- Its facilities and equipment received a positive opinion of the competent sanitary inspector;

- It presents a draft quality assurance system referred to in art. 29.

The permission is granted for a period of 5 years (art. 26, item 4 of the Transplant Act).

The entity subject to inspection should expect the following two main areas to be covered:

- fulfillment of the conditions required to obtain a permit, i.e. any requirements on the qualification of employees, premises and equipment, and the quality assurance system. The quality assurance system involves the following documents:

- standard operating procedures:

- guidelines;

- code of conduct;

- reporting forms;

- donor cards;

- information on the final destination of tissues or cells.

PERMIT APPLICATION PROCESS

A. Up to 1 month

A1. Up to 7 days upon receipt of the notification

B. Up to 1 month

C. Up to 1 month since the receipt of recommendations

D. Up to 7 days before the inspection

E. Up to 14 days upon ending the inspection

E1. Up to 14 days upon the receipt of the post-inspection protocol

E2. Up to 14 days upon submitting objections

F. Up to 1 month upon the receipt of the report on the implementation of postinspection recommendation

G. Up to 1 month since positive verification of introduced recommendations

H. Up to 1 month upon the receipt of the post-inspection conclusion from the Center

I. Up to 1 month since KRT session

J. Up to 1 month upon the receipt of KRT opinion

K. Operations upon the decision of the Ministry of Health
The Centre carries out formal assessment of the application and in case of a positive result requests the Minister of Health to carry out an inspection in the entity that submitted the application

The proposal does not meet formal requirements. The Center calls the applicant to rectify the shortcom ings with the instruction that failure to remedy the deficiencies within the prescribed period results in leaving the application without consideration.

The Minister of Health conducts or recommends conducting inspection by the Center in the entity that submitted the application. (art. 35 item 2 of the Transplant Act). (See details of the inspection below)

The Centre sets a deadline of control of the applicant.

The Centre notifies the entity about the date of the inspection and its scope.

On the basis of the application observations of the inspection and submitted documents, inspection protocol is prepared, and its two copies signed by inspectors are forwarded to the auditee.

The audited entity may submit objections to the submitted protocol or accept it and undertake the recommendations made during the audit, relating to the removal of shortcomings (misconduct, non-compliance). In the case of the approval of such a protocol the entity signs and returns one of the received copies and sends it to the Center with a timetable covering the implementation of the recommendations made. In the case of objections to the protocol, the entity submits them to the Minister of Health.

Minister takes into account or rejects the objection in his final decision.

Upon receiving the letter on the implementation of recommendations with accompanied evidence, the Center conducts the assessment of the submitted documents.

The Center applies to the Minister of Health for issuing the permit to the entity in accordance with its request indicated in the application including post-inspection report in the application.

The Minister of Health shall forward the application, together with copies of attached documents to the National Transplant Council (hereinafter KRT) for the review of the application (art. 26 item 3 of the Transplant Act).

During the following session KRT issues its opinion on the request of the Center forwarded by the Minister of Health, and the Chairman of KRT forwards its opinion to the Minister of Health.

The Minister of Health shall assess whether the entity applying for the permit and its subcontracting entities meet the statutory conditions and decides whether to issue or to refuse the permit.

The Center is notified by the Minister of Health about having issued a decision and in the case of a decision to grant the permit it enters the biobank's data on the public website. In case of a negative decision, the entity requesting the permit may apply to the Minister of Health for reconsideration of the case in accordance with art. 127 of the Code of Administrative Procedure (OJ 2016 pos. 23). 
Specific requirements regarding the quality system that should be met by the biobank have been included in the Regulation of the Minister of Health of 9 October 2008 on the requirements to be met by a quality assurance system in the biobank (Journal of Laws 2008 No 190, item 1169).

- meeting further requirements of the Act in respect to:

- labeling and packaging of tissues or cells and documenting these activities. Requirements on labeling, monitoring and criteria for safety and quality of cells and tissues and organs are provided for by art. 7b-37e of the Transplant Act, and the Regulation of the Minister of Health of 2 April 2010 on the unique marking and monitoring of cells, tissues and organs (Journal of Laws 2010 No. 75, item 486);

- ensuring the highest quality of tissues and cells during their distribution;

- storage of tissues and cells under monitored conditions;

- labelling of cells, tissues or organs in a way that allows the identification of a donor using a unique code (according to the Regulation of the Minister of Health of 2 April 2010 on the unique marking and monitoring of cells, tissues and organs);

- collection and storage of documentation;

- security and protection against unauthorized data additions, deletions or modifications;

- medical records of donors and transfer of information to unauthorized persons;

- the procedure to resolve data discrepancies;

- providing protection against unauthorized disclosure of data, ensuring monitoring capacity of the tested cells, tissues or organs;

- conducting the validation of all processes;
The range of characters for the unique marking for the collection of:

- bone marrow and hematopoietic cells of peripheral blood from 4000 to 4099;

- hematopoietic cells of umbilical cord blood - from 4100 to 4199;

- cells, tissues and regenerating cells or tissues other than bone and hematopoietic cells of peripheral blood, umbilical cord blood - from 4200 to 4299 ;

- vascularized organs - from 4300 to 4399 .

Additional labeling information allowing for identification:

- country of collection;

- name and address of the entity collecting cells, tissues or organs;

- year of collection;

- serial number of collection;

type of cells, tissues or organs collected;

- type of collection;

class, attribute and modifier defining the operation of processing or storage;

medical products and materials in direct contact with the cells, tissues or organs.

- identification of critical moments of all the processes that should be controlled based on the determined acceptance criteria;

- conducting qualification of the equipment, technical devices and the environment hosting the process;

- entering into agreements with entities collaborating, cooperating with collection teams and concluding contracts for storage with natural persons;

- exporting or importing tissues and cells, respectively, from and to the Polish territory.
Responsibilities of a biobank in regard to other entities

The fact that biobanks have obligations to verify whether any entity, whose activities affect the quality and safety of tissues and cells processed in cooperation with the entity, complies with certain criteria of the Transplant Act, is not without significance. It is also important in respect to the assessment of a biobank whether it conducts genetic tests (e.g. typing for transplantation of hematopoietic stem cells, the detection and identification of antibodies), sequences DNA or modifies genetic material.

Any biobank is obliged to respect the rules of data protection, as personal data concerning a potential donor, the donor, the potential recipient and the recipient are confidential and shall be protected under legal requirements of professional and business secrecy and the provisions relating to medical records maintained by medical entities (art. 19 of the Transplant Act).

\section{Acceptability of compensation}

The only act in international law that regulates the issue of researches on biological material is a soft law reflected in the Recommendation of the Council of Europe (2006) on research on human biological material. This act emphasizes the general obligation to inform and obtain informed consent from donors of biological material, both in the case where the material is collected for a particular biomedical experiment and when it has been previously collected to conduct another experiment or for any other purpose than scientific.

The reasons for this are complex. First of all, there are big differences in normative terms as for the status of the human body and its parts in individual countries. The European law has prohibited the commercialization 
of the human body and its parts what is reflected in art. 3 item 2 of the Charter of Fundamental Rights of the European Union (the principles of non-commerciality), art. 21 of the European Convention on Bioethics and art. 7 of the Recommendations of the Council of Europe (2006) (Jabłońska, 2013, 123-125). Concretization of the principles of exclusion of the human body and its parts from the market is regulated by the Biotech Directive, which contains a provision on the prohibition of patenting the human body and its elements, as well as techniques recognized as violating public order and morality (art. 5 and 6 of the Directive). Domestic legal orders about this issue are also treated variously. In Germany, for example, parts of the human body that have been disconnected (isolated) are can be traded, but must not be a source of financial income. In Britain, the Human Tissue Act 2004 does not give a man any property rights to the biological material originating from his body but some courts seem to allow the possibility of treating the human body as an object. In Poland, the provisions of the Transplant Act exclude biological material from the market which is treated as res extra commercium.

Secondly, a very big social and ethical controversy arises from the issue of maintaining the appropriate balance between two factors: business benefits and social benefits from the commercial use of results of researches on biological material. The conflict between business and public interest is fueled by the issue of protecting rights of individual donors of biological material. In this context, there are two groups of views to be highlighted. The first one states that research on human biological material are less ethically controversial because they involve less risk for the patient and therefore can and should be conducted for the common good, in line with the principle of freedom in scientific researches. The second group says that due to the fact that third parties can get access to information about a man (and often more people related with him) as a result of research on human biological material, there is a risk of violation of fundamental values such as dignity, autonomy, privacy and protection personal data of the donor material.

In Poland, the provisions of the Transplant Act exclude biological material from the market. Such biological material are large organs (kidney, lung, heart), and cells and tissues of skin or blood stem cells.

Above all, Poland is not yet a part to the European Convention on Bioethics (the Convention was signed by Poland on 7 May 1999, But has not been ratified until now). Nevertheless, even if the Polish law prohibiting commercialization of the human body and its parts could not be stemmed directly from art. 21 of the Convention on Bioethics, this rule will result from the system of protection of personal interests adopted in the Polish legislation and settled in the Polish case law, as well as legal concept reflected in the literature that the human body and its parts must be classified as elements closely related to the personality of man; and thus belong to the realm of his personal rights. Consequently, such a protection and disposing of the human body and separated parts of the human body are subject to the wider regime of protection of personal interests (personal interests that come into play here, especially psychological integrity, personal inviolability, health, life, privacy, etc.). According to the judgment of the Supreme Court of 5 July 1973, III CRN 161/73, conducting various medical and anthropological researches, examinations, collection of fingerprints, blood, hair, body secretions, etc. can lead to the violation of personal rights, including his physical integrity. In this context as well, the issue of consent of the holder is particularly important.

Such an interpretation is favored by the reference to the definition laid down in Directive 2004/23/EC of the European Parliament and of the Council as re- gards traceability requirements, notification of serious adverse reactions and events and certain technical requirements for coding, processing, preservation, storage and distribution of tissues and cells human (EU OJ L 294, 25.10.2006, p. 32).

Art. 3 of the Transplant Act introduces the principle of free donation of tissues, cells and organs. Art. 3 item 1 of the Transplant Act expressing this rule says that no payment or any other pecuniary or personal benefit can be requested or accepted due to the collection of cells, tissues or organs from the donor. This provision correlates with the prohibition of the commercialization of the human body and its parts expressed in the EU and international documents mentioned above. On the other hand, art. 36 states that proceedings on the cells, tissues and organs in the meaning of their collection from living donors may be carried out only by entities operating in the field of medical treatment within the meaning of the Act of 15 April 2011 on medical activity, and having permits issued by the minister responsible for health affairs for performing such activities (art. 36 p. 1a of the Act). This provision imposes the obligation for any biological material to be collected only by authorized institutions. At the moment, in the light of Polish regulations, collection of any biological material for research can be conducted only by a doctor and a dentist (but not by, for example, a geneticist, biologist or biochemist).

A biobank must not also pay compensation to the healthcare entity that provides organs, tissues or cells in the amount exceeding any necessary return for incurred costs and burdens associated with the storage of biological material, the additional protection balanced with the lack of costs associated with the disposal of collected biological material. A biobank does not have to provide any payments or rewards for donors, if they do not incur any additional costs or burdens when their bi- 
ological material is collected on the occasion of another surgery which they decide for independently from the decision of forwarding their living biological material to a biobank. In the result, there is no problem with the assessment of excessive rewards or payments that would encourage to donate organs for remuneration (which is in turn would be subject to the charges on trafficking of human biological material) or constitute too high incentive for a donor of biological material that would prevent him from making conscious decision.

The ban on compensation for donated tissues and cells does not prohibit the biobank against the collection of fees for the transportation of tissues or cells, their storage or processing or cultivation, and for the transportation of collected cells or tissues to the healthcare entity conducting transplantation (pursuant to art. 3 of the Transplant Act). The interpretation of these provisions leads to the conclusion that return of costs is due the entity conducting given actions, not the entity of the donor.

\section{Conclusions}

Undertaking business activity as a biobank demands meeting a number of legal requirements, and obtaining the permit is time-consuming. Nevertheless, conducting business activity as a biobank allows to earn certain income and to develop space laboratory. Currently there is no law regulating operation of biobanks in Poland. There are also a lot of questions of ethical and legal nature in conducting a biobank. Their activity is particularly governed by the right to privacy and requirements relating to the so-called, prior obtained and informed consent for the use of biological material, but the contents of the received statement may raise a number of concerns, and ultimately the final content of the consent on the specific handling of the biological material may be difficult to determine. The number of restrictions is significant; however, it does not mean that the establishment of a biobank is elusive. There are 44 biobanks of different range of specialties regarding collected tissues and cells in Poland registered in the KCBTiK register. Biobanks operating on the market are located predominantly at hospitals and universities. Therefore, these are entities supporting activities of hospitals and university hospitals, certainly not geared to achieving significant financial benefits.

\section{References}

Convention for the Protection of Human Rights and dignity of the human being to the Application of Biology and Medicine of 4 April 1997, by Oviedo (European Convention on Bioethics; http://www.coe.int/t/dg3/healthbioethic/texts_and_documents/ http://www.coe.int/t/

The Charter of Fundamental Rights of the European Union (OJ EU C 83, 30.3.2010 P.0389-0403)

Recommendation of the Council of Europe (2006) on Research on Biological Material of Human Origin (http://www.coe.int/t/dg3/ healthbioethic/texts_and_documents/Rec_2006_4.pdf);

Declaration of Helsinki, Ethical Principles for Medical Research Involving Human Subject, adopted in June 1964 in Helsinki by the $18^{\text {th }}$ General Assembly of the World Medical Association (World Medical Association)

Directive 2001/20/EC of the European Parliament and of the Council of 4 April 2001 on the approximation of the laws, regulations and administrative provisions of the Member States relating to the implementation of good clinical practice in the conduct of clinical trials on medicinal products intended for use by a lack of human (OJ. L 121, 01/05/2001 P. 0034 - 0044)

Directive 2004/23/EC of the European Parliament and of the Council of 31 March 2004 on setting standards of quality and safety for the donation, procurement, testing, processing, preservation, storage and distribution of human tissues and cells (OJ L 102, 07 / 04/2004 P. 0048 - 0058)

Directive 2008/98/EC of the European Parliament and of the Council of 19 November 2008 on waste and repealing certain Directives (OJ L 312, 22/11/2008 P. 0003)

The Act of 15 April 2011 on medical activity (Journal of Laws of 2015 pos. 618 , as amended)

Act of 1 July 2005 on the collection, storage and transplantation of cells, tissues and organs (Journal of Laws of 2015, item. 793, as amended, pos. Transplant Act)

Act of September 6, 2001. Pharmaceutical Law (Journal of Laws of 2015 pos. 464 , as amended)

Act of 30 March 2001 on cosmetics (Journal of Laws of 2013 pos. 475) Act of 5 December 1996 on professions of doctor and dentist (Journal of Laws of 2015 pos. 464 , as amended)

The decision of the US Supreme Court on the subject matter

Konwencja o ochronie praw człowieka i godności istoty ludzkiej wobec zastosowań biologii i medycyny z dnia 4 kwietnia 1997 r. z Oviedo (Europejska Konwencja Bioetyczna; http://www.coe. int/t/dg3/healthbioethic/texts_and_documents/ETS164Polish. pdf)

Karta Praw Podstawowych Unii Europejskiej (Dz. Urz. UE C 83, 30/3/2010 P.0389-0403)

Rekomendacja Rady Europy (2006)4 dotycząca Badań Naukowych Ludzkiego Materiału Biologicznego (http://www.coe.int/t/dg3/ healthbioethic/texts_and_documents/Rec_2006_4.pdf);

Deklaracja Helsińska, Etyczne Zasady Prowadzenia Eksperymentów Medycznych z Udziałem Ludzi, przyjęta w czerwcu 1964 r. w Helsinkach przez 18 Zgromadzenie Ogólne Światowego Stowarzyszenia Lekarzy (World Medical Association)

dyrektywa 2001/20/WE Parlamentu Europejskiego i Rady z dnia 4 kwietnia $2001 \mathrm{r}$. w sprawie zbliżania przepisów ustawowych, wykonawczych i administracyjnych państw członkowskich, odnoszących się do wdrożenia zasady dobrej praktyki klinicznej w prowadzeniu badań klinicznych produktów leczniczych, przeznaczonych do stosowania przez brak człowieka (Dz. Urz. L 121, 01/05/2001 P. $0034-0044$ )

dyrektywa 2004/23/WE Parlamentu Europejskiego i Rady z dnia 31 marca 2004 r. w sprawie ustalenia norm jakości i bezpiecznego oddawania, pobierania, testowania, przetwarzania, konserwowania, przechowywania i dystrybucji tkanek i komórek ludzkich (Dz. Urz. L 102, 07/04/2004 P. 0048 - 0058)

dyrektywa 2008/98/WE Parlamentu Europejskiego i Rady z dnia 19 listopada 2008 r. w sprawie odpadów oraz uchylająca niektóre dyrektywy (Dz. Urz. L 312, 22/11/2008 P. 0003)

Ustawa z dnia 15 kwietnia 2011 r. o działalności leczniczej (t. jedn. Dz.U. 2015, poz. 618 z późn. zm.)

ustawa $\mathrm{z}$ dnia 1 lipca 2005 r. o pobieraniu, przechowywaniu i przeszczepianiu komórek, tkanek i narządów (t. jedn. Dz. U. 2015 poz. 793 z późn. zm., poz. ustawa transplantacyjna)

ustawa $z$ dnia 6 września 2001 r. Prawo farmaceutyczne (t. jedn. Dz.U. 2015, poz. 464 z późn. zm.)

ustawa z dnia 30 marca 2001 r. o kosmetykach (t. jedn. Dz.U. 2013, poz. 475)

ustawa z dnia 5 grudnia 1996 r. o zawodach lekarza i lekarza dentysty 
(t. jedn. Dz.U. 2015, poz. 464 z późn. zm.)

Orzeczenie SN USA w sprawie Moore v. The Regents of the University of California, 1991, 793 P.2d 479, cert. denied, 499 U.S. 936 (1991)

Orzeczenie Court of Appeal of California, Baldwin v. Marina City Properties Inc., 1978, 79 Cal App. 3d 393

Wyrok SN z dnia 5 lipca 1973 r., III CRN 161/73

Orzeczenie Court of Appeal of California w sprawie Magan Medical Clinic v. California, State Bd. Of Medical Examiners, 1967, 249 Cal. App. 2d 132

Banaszczyk Z., Boratyńska M., Borysiak W., Bosek L., Janiszewska B., Safjan M., Sobolewski P., Safan M. red. (2011). Prawo wobec medycyny i biotechnologii. Zbiór orzeczeń $z$ komentarzami. Warszawa

Beyleveld D., Why rectical 26 of the Directive on the legal protection of biotechnological inventions should be implemented in national law?. IPQ.1

Czarkowski M. (2009). Zasady prowadzenia badań na ludzkim materiale biologicznym. Polski Merkuriusz Lekarski. 27

Czarkowski M., Różańska J. (2008). Świadoma zgoda na udział w eksperymencie medycznym. Ośrodek Bioetyki Naczelnej Izby Lekarskiej. Naczelna Izba Lekarska. Warszawa

E.U Group of Advisers on the Ethical Implications of Biotechnology (1996). Ethical Aspects of Patenting Inventions Involving Elements on Human Origin

Ferrell J.E. (1990). Who Owns John Moore`s Spleen?. Chicago Tribune. 18.02 .1990

Grzymkowska M. (2009). Standardy bioetyczne w prawie europejskim. Warszawa

Hardcastle R.. (2007). Law and the Human Body. Property Right, Ownership, Control. Hart Publishing

Harvey T., McHaley J.V. (2004). Health Law and the European Union. Cambridge

Jabłońska J. (2013). Prawo do integralności w Karcie Praw Podstawowych Unii Europejskiej W: Kondratiewa-Bryzik L., Sękowska-Kozłowska, Prawa człowieka wobec rozwoju biotechnologii, Warszawa

Komender J. (2004). Podstawy prawne funkcjonowania banków tkanek. W: Dziedzic-Gocławska A., Ostrowski K., Komender J., Michalik J... Stachowicz W, 40 lat bankowania i sterylizacji radiacyjnej tkanek $w$ Polsce. Przeszczep $w$ walce $z$ kalectwem. Warszawa:13-17

Kondratiewa-Bryzik L., Sękowska-Kozłowska K. (red.) (2013). Prawa człowieka wobec rozwoju biotechnologii. Warszawa

Kosieradzki T., Kowalska J. (2006). Zgoda na udział w badaniu klinicznym. Evidence Based Medicine, cz. 2. Stużba Zdrowia.18-21

Krajewska A. (2010). Badania naukowe na ludzkim materiale biologicznym. W: Różyńska J., Waligóra M. Badania naukowe z udzia- łem ludzi w biomedycynie. Standardy międzynarodowe, Warszawa Kubiak R. (2000). Zgoda uczestnika eksperymentu, cz. I. Prawo i Medycyna. 8.2.6

Lunshof J.E. [i in.] (2008). From Genetic Privacy to Open Consent. Nature Reviews Genetics. 9:406-411

Mason J.K., Laurie G. (2011). Mason and McCall Smith's Law and Medical Ethics. Oxford

Pawlikowski J. (2015). Dyskusja wokół koncepcji świadomej zgody w kontekście badań naukowych z użyciem ludzkiego materiału biologicznego. Diametros. 44

Rada Europy (2011). Poradnik dla członków komisji etycznych do spraw badań naukowych. Strasburg. 7 lutego 2011. CDBI/INF.2 Skloot R. (2011). Kobieta ważąca $50 \mathrm{mln}$ tom. Focus.7

Taupitz J., Weigel J. (2012). The Necessity of Broad Consent and Complementary Regulations for the Protection of Personal Data in Biobank: What Can We Learn from the German Case? Public Health Genomics. 15:5

Temmerman M. (2007). Human Rights in the Patent Procedure. The Issue of Prior Informed Consent of Human Donors to the Patenting of Inventions based upon their Genetic Material. Working Paper. 